\title{
The Study Application of Water Hyacinth Biofertilizer Towards the Existence of Endophytic Bacteria in Maize Plant
}

\author{
Yun Sondang ${ }^{1, *}$ Ramond Siregar ${ }^{1}$ Khazy Anty ${ }^{1}$ \\ ${ }^{1}$ Department of Food Crop, Payakumbuh State Agriculture Polytechnic \\ *Corresponding author, Email: silitongayun27@gmail.com
}

\begin{abstract}
Endophytic bacteria are bacteria that live in plant tissue without destroying the host plant. The presence of endophytic bacteria in plant tissue can produce phytohormones to stimulate growth and increase plant resistance to disease. The purpose of this study is to identify endophytic bacteria from the root tissue of maize plants treated with water hyacinth biofertilizer and to calculate the number of bacterial populations. The research was conducted at the Experimental Garden and Laboratory of the Payakumbuh State Agricultural Polytechnic. The treatments of biofertilizer were carried out by immersing the seeds in biofertilizer $4 \%$ solution for 12 hours, then maize plants were treated with a biofertilizer in the planting hole, and the age of the plants was $14,28,42,56$ days after planting. Observation parameters were carried out on endophytic bacteria of the maize plant and the number of bacterial populations. Identification of bacterial morphology based on colony shape, colony edges, colony elevation, surface, color, bacterial density, and gram staining. Bacterial species were identified using molecular analysis based on the 16S rRNA gene fragment. The identification results of maize root endophytic bacteria found 4 dominant bacterial with several bacterial populations species such as B. paramycoides $12,1 \mathrm{x}$ $10^{7} \mathrm{CFU} / \mathrm{ml}$, P. aeruginosa $4,3 \times 10^{7} \mathrm{CFU} / \mathrm{ml}, B$. subtilis $9,4 \times 10^{7} \mathrm{CFU} / \mathrm{ml}$, and B. licheniformis $5,95 \times 10^{6}$ $\mathrm{CFU} / \mathrm{ml}$.
\end{abstract}

Keywords: Endophytic bacteria, Identification, Water hyacinth, B. licheniformis

\section{INTRODUCTION}

Most of the bacteria that act as biofertilizers are closely related to bacteria in plant roots and the rhizosphere. The colonization of bacteria that live in plant tissue without destroying the host plant is called endophytic bacteria. Endophytic bacteria are endosymbiotic microorganisms that fill the space between cell walls [1] and the xylem vessels of roots, stems, leaves of plants [2], and protect plants from pathogens that cause disease [3]. Some of the main activities of host plants are influenced by the presence of endophytic bacteria [4]. Endophytic bacteria are one of the sources of extracellular compounds in the form of enzymes (chitinase, protease, cellulose). Enzymes from endophytic bacteria are more beneficial and produce faster. According to $[1,5]$ that endophytic bacteria provide several benefits for host plants such as plant growthpromoting activity, modulation of plant metabolism, and phytohormones signaling. This bacterial activity is often used by researchers and industry as materials for making biofertilizer products, and the biotechnology industry to produce antibiotics [6].
The response varies by endophytic bacteria depend on the genotype and host environment, competition from endogenous microorganisms, a specificity of the host genotype, poor formation, and persistence. Ref. [7] stated that the application of minerals or organic fertilizers had a different effect on the composition of the microbial community and microbial biomass. Several previous research results stated that endophytic bacteria can influence plant growth directly or indirectly. The presence of endophytic species is highly dependent on plant factors and bacterial genotypes, biotic and abiotic environments [1]. Endophytic bacteria play a role in maintaining the physiological balance of plants and the agroecosystems. According to [8] endophytes affect plant growth through $\mathrm{N}$ fixation, phytohormone production, nutrient acquisition, and tolerance to abiotic and biotic stresses.

The ability of bacteria to enter and develop in plant tissue makes endophytes unique, demonstrating multidimensional interactions within the host plant [4]. Endophytic bacteria can produce secondary metabolites that can affect plant growth and protect plants from 
pathogens. This is the basis for the isolation and characterization of beneficial bacteria to be used in creating biological products for sustainable agriculture. Research on the effect of providing biofertilizers on the diversity of endophytic bacteria has been carried out. This study aims to identify and determine the population abundance of endophytic bacteria from the root tissue of maize plants treated with water hyacinth biofertilizers, and their potential as a plant growth promoter.

\section{MATERIALS AND METHODS}

\subsection{Time and Research Place}

The research was carried out at the Experimental Garden and Laboratory of the Payakumbuh State Agricultural Polytechnic, Harau District, Limapuluh Kota Regency, West Sumatra, Indonesia from March to July 2020.

\subsection{Tools and Materials}

The tools used are Erlenmeyer, petri dish, mortar, test tube, PCR, and analytical scale. The materials are biofertilizer water hyacinth, Pioneer 32 maize seeds, roots of maize plants that have been treated with biofertilizer, $10 \%$ sodium hypochlorite, $70 \%$ alcohol, distilled water, Nutrient Agar, Pikovskaya agar, Safranin, and crystals violet.

\subsection{Research Procedures}

The cultivation was started with the corn seeds of Pioneer 32 varieties soaked in bacterial suspension with a density of $10^{7} \mathrm{CFU} / \mathrm{ml}$ at room temperature $\pm 30{ }^{\circ} \mathrm{C}$ for 12 hours (seed treatment). Corn seeds were planted at a spacing of $70 \times 25 \mathrm{~cm}$. Biofertilizers were applied to the planting hole during planting and sprayed on to plant leaves (foliar treatment) at the ages of 14, 28, 42, and 56 days after planting. Maize plants are maintained until the age of 110 days. At the age of 110 days, the plants were uprooted and part of the root fibers are taken to identify the endophytic bacteria found in the roots.

\subsection{Endophytic Bacteria Identification}

Endophytic bacteria were isolated by cutting the roots of maize plants and washing them with running water until they were clean, then dried. The roots were weighed $1 \mathrm{~g}$ and sterilized sequentially by immersing in $70 \%$ alcohol for 30 seconds, immersed in $2 \%$ sodium hypochlorite for 1 minute, immersed in $70 \%$ alcohol for 30 seconds. The roots soaked in sterile water 3 times for 1 minute each. The roots were crushed in a mortar and put into an Erlenmeyer, then added with distilled water up to $10 \mathrm{ml}$ and stirred evenly $\left(10^{-1}\right.$ dilution).
Furthermore, the dilution is carried out to $10^{-7}$. The $10^{-7}$ solution was taken $0.1 \mathrm{ml}$ and spread on Natrium agar and Pikovskaya agar media. See the development of bacteria on the third day. The growing bacteria were isolated and grown on the same media until pure bacterial isolates were obtained.

Pure bacterial isolates were identified visually based on colony shape, colony edge, colony surface elevation, colony surface, color, colony density, and gram stain. The next stage of identification using a PCR tool. The PCR results were sequenced using the Sanger method to determine the DNA sequence and matched using the BLAST device. PCR amplification on 16S rRNA using Primer $27 \mathrm{~F}$ and Primer $1492 \mathrm{R}$ [9]. The sequencing results were processed using the BioEdit program and in BLAST with genomic data that had been registered at NCBI to determine species based on molecular homology.

\subsection{Bacterial Population Calculations}

The bacterial population was calculated using the Total Plate Count (TPC) method. Bacterial samples are streaked and dissolved into a test tube containing $10 \mathrm{ml}$ of sterile distilled water $\left(10^{-1}\right.$ dilution $)$. Then a serial dilution to $10^{-4}$ was made. Each $10^{-1}-10^{-4}$ dilution was taken as much as $200 \mu \mathrm{L}$ and spread evenly into a petri dish containing NA medium. Petri dishes were incubated at $35^{\circ} \mathrm{C}$ for $2 \times 24$ hours. The population of bacteria growing on the surface of the media was calculated using a formula

Bacterial density $=$ Colony count $x \frac{1}{(\text { Dilution factor })} \times\left(\frac{\mathrm{CFU}}{\mathrm{ml}}\right)$

\section{RESULT AND DISCUSSION}

The results of isolation endophytic bacteria originating from the roots of maize plants that have been given biological fertilizers obtained 9 bacterial isolates, but only 4 dominant bacteria were taken (total population > $\left.10^{6} \mathrm{CFU} / \mathrm{ml}\right)$. Several research results showed that the bacteria in the roots have more types and populations than those on the leaves and stems of plants. The opinion of [10] states that in rice plants, the population density of endophytic bacteria in roots and other underground tissues is higher than that of the leaves and stems of plants. The morphology of bacterial isolates based on colony shape, colony edge, colony elevation, surface, color, bacterial density, and gram staining is shown in Table 1 and bacterial isolates can be seen in Figure 1 below.

Bacterial isolates (Aa, Ab, Ac, Ad) showed a round shape, entire until the undulate edge of the colony, elevation raised, smooth surface, cream color, and a 
dense population of bacteria. The staining results of all Bacillus sp including gram-positive and Pseudomonas isolates were gram-negative. The results of the $16 \mathrm{~S}$
rRNA sequence of endophytic bacterial species can be seen in Table 2. The role of each bacteria and its researchers can be seen in Table 3.

Table 1. Morphology of bacterial isolate

\begin{tabular}{cccclllc}
\hline Isolate code & Colony shape & Colony edge & Colony elevation & Surface & Color & Density & Gram \\
\hline $\mathrm{Aa}$ & round & Undulate & raised & smooth & cream & solid & + \\
$\mathrm{Ab}$ & round & entire & raised & smooth & cream & solid & - \\
$\mathrm{Ac}$ & round & entire & raised & smooth & cream & solid & + \\
$\mathrm{Ad}$ & round & undulate & raised & smooth & cream & solid & +
\end{tabular}

Information: $\mathrm{Aa}=$ Root $\mathrm{a}, \mathrm{Ab}=\operatorname{Root} \mathrm{b}, \mathrm{Ac}=\operatorname{Root} \mathrm{c}, \mathrm{Ad}=\operatorname{Root} \mathrm{d}$

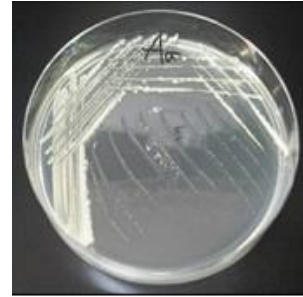

$\mathrm{Aa}$

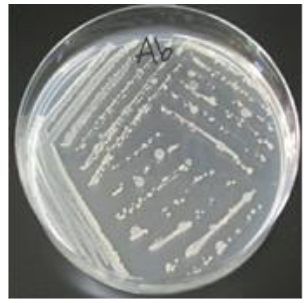

$\mathrm{Ab}$

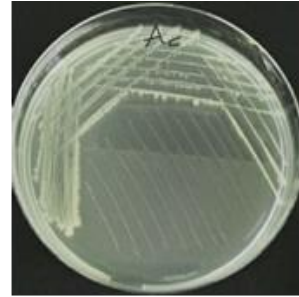

Ac

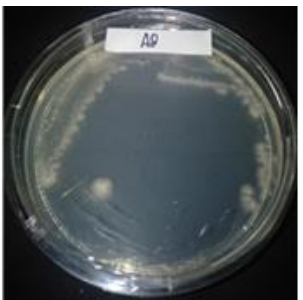

$\mathrm{Ad}$

Figure 1: Isolate bacteria

Table 2. The results of the $16 \mathrm{~S}$ rRNA sequence of species of endophytic bacteria

\begin{tabular}{clccc}
\hline Isolate code & \multicolumn{1}{c}{ Species of bacteria } & Strain & Homology (\%) & $\begin{array}{c}\text { Number of colonies } \\
(\mathrm{CFU} / \mathrm{ml})\end{array}$ \\
\hline $\mathrm{Aa}$ & Bacillus paramycoides & MCCC 1A04098 & 99,57 & $12,1 \times 10^{7}$ \\
$\mathrm{Ab}$ & Pseudomonas aeruginosa & ATCC 10145 & 99,92 & $4,3 \times 10^{7}$ \\
$\mathrm{Ac}$ & Bacillus subtilis & $H R-4$ & 99,85 & $9,4 \times 10^{7}$ \\
$\mathrm{Ad}$ & Bacillus licheniformis & $D S M 13$ & 99,79 & $5,95 \times 10^{6}$ \\
\hline
\end{tabular}

Table 3. The role of bacterial species

\begin{tabular}{ll}
\hline Bacterial species & $\begin{array}{l}\text { The role of bacteria and } \\
\text { researchers }\end{array}$ \\
\hline Bacillus paramycoides & $\begin{array}{l}\text { Amylose production [11], } \\
\text { amylolytic production [12] }\end{array}$ \\
Pseudomonas aeruginosa & $\begin{array}{l}\text { N-fixing, P solvent, } \\
\text { antagonistic bacteria, PGPR }\end{array}$ \\
& [13], enzyme amylase [11] \\
N-fixing, P solvent, IAA \\
production [14], \\
antagonistic bacteria [15], \\
antibiotic, bacteriocins [2], \\
cytokinin production [16] \\
Denitrification [17], \\
enzyme APPM production \\
[18], $\alpha$-amylase production \\
Bacillus licheniformis & [19], protease production \\
&
\end{tabular}

All bacterial species in Table 2 are found in all maize roots that are treated with water hyacinth biofertilizer with different population densities. The roots of maize plants treated with biological organic fertilizers were dominated by Bacillus spp. followed by Pseudomonas sp. The type and population of bacteria are determined by the type of plant and the plant environment. The types of bacteria that are in plant root tissue depend on the synergy between bacteria, which means that bacteria are strong and can work together that live in the tissue. The application of biofertilizer is one of the environmental factors that affect the diversity of bacteria in maize. Bacteria can come from the leaf surface (foliar treatment), from plant roots that come from the soil, both soil treatment and free bacteria in the soil. It is suspected that the bacteria that live in the root tissue of cultivated plants are influenced by the treatment of liquid organic fertilizer on the leaves, soil processing techniques, and the treatment of biofertilizers 
applied to the soil. The abundance of microbial populations depends on soil type, age, and plant conditions.

The biofertilizer of water hyacinth that given to maize plants contains the bacteria $P$. aeruginosa strain WCHPA075019 $2.8 \times 10^{8} \mathrm{CFU} / \mathrm{ml}$, B. subtilis subsp. subtilis strain $1684.3 \times 10^{7} \mathrm{CFU} / \mathrm{ml}$, and B. cereus $2.8 \times$ $10^{7} \mathrm{CFU} / \mathrm{ml}$. Bacteria were identified 6 weeks after making organic fertilizer. The application of organic fertilizers will increase the diversity of microbes and increase metabolic activity significantly [1]. Biofertilizers are applied to seeds or soil, which will reproduce and participate in the movement of nutrients, thereby increasing plant productivity [21].

Table 3 shows that each bacteria has its role. Bacillus paramycoides and Bacillus licheniformis can produce amylase and other enzymes. Pseudomonas aeruginosa and Bacillus subtilis act as N-binding bacteria, $\mathrm{P}$ solvent, and antagonistic bacteria. Researchers [22] stated that the features of several Bacillus spp species are that they live on plant roots without causing damage to the host plant, as well as being able to suppress plant diseases caused by pathogenic bacteria, systemic viruses, and spot fungi.

The results of the 16S rRNA sequence homology of Aa bacterial isolate were similar to $B$. paramycoides strain MCCC $1 \mathrm{~A} 04098$ with a homology level of $99.57 \%$. This isolate is the dominant bacteria in the endophyte of maize plants. These bacteria are known as amylolytic bacteria which can break down starch into glucose. The researcher [11] found $B$. paramycoides bacteria in mangrove sediments that can convert starch into glucose. Ref. [12] states that B. paramycoides can produce amylolytic enzymes and develop well in media that contain lots of carbohydrates with an acidity of $\mathrm{pH}$ 5-9. The Researcher [23] found B. paramycoides in South China ocean sediments as a new strain of the B. cereus group. As well [24] to found B. paramycoides in the root network of maize plants in the Taram and Kandang Lamo areas in Limapuluh Kota Regency, West Sumatra. In B. paramycoides isolates were identified to show a halo zone around the bacterial colony, this indicates that these bacteria can dissolve phosphate. According to Ref. [25], B. paramycoides is a grampositive bacteria with the cell form of basil.

$P$. aeruginosa (Ab isolate) is a bacterium with a negative gram stain (Table 1), capable of dissolving $\mathrm{P}$, and acts as PGPR (Table 3). Ref. [13] stated that $P$. aeruginosa acts as PGPR with the synthesis mechanism of HCN, siderophore, and polar substance. Research by [26] shows bacteria from the Pseudomonas spp. can increase plant growth and development due to increased $\mathrm{P}$ nutrient uptake by plants and the contribution of growth stimulants GA3. Ref. [27] found that $P$. aeruginosa isolated from wheat plants has been shown to withstand biotic and abiotic stresses in cucumber plants through phenylpropanoid metabolism, antioxidant activity, and proline accumulation. The results of the research by [11] that $P$. aeruginosa is an amylolytic bacteria that has the potential to degrade starch into compounds that are simpler and relatively easy to dissolve in water.

An isolate of bacteria Ac was similar to B. subtilis bacteria are antagonistic bacteria that live in water, air, soil, and rotting plant residues. Several species of Bacillus sp. have potential as biological agents [15]. The genus Bacillus has interesting physiological properties, where each species has different abilities, including 1) able to degrade organic compounds such as starch [11], 2) able to produce antibiotics [2], 3) play a role in nitrification and denitrification [17], 4) nitrogen-fixing, 5) chemoautotrophs, aerobic or facultatively anaerobic [23].

The results of previous research by [24] showed that $B$. licheniformis was found in endophytes of maize plants whose soil was contaminated with building lime waste in the village of Tanjung Pati, West Sumatra. According to [28] the consortium of B. licheniformis, $B$. subtilis, and $B$. cereus has been widely used by the commercial seed industry as a degradation agent in paint water waste treatment. B. licheniformis strain DSM 13 is closely related to B. subtilis [17]. This bacterium is used in the biotechnology industry to produce enzymes, antibiotics, and biochemistry. These bacteria generally live in soil, terms of these bacteria are in the plant endosphere because the bacteria have succeeded in colonizing the roots and entering the tissue.

Reported [19] two strains of B. licheniformis bacteria that can produce $\alpha$-amylase enzymes. This enzyme is stable at acidity $\mathrm{pH} \mathrm{7-9}$ and temperature $37^{\circ} \mathrm{C}$. B. licheniformis can produce a destroying enzyme (APPM) which can break down the starch substrate in the cassava peel into liquid sugar [18]. In general, the genera Bacillus can grow and develop under aerobic conditions, however, B. licheniformis lives in facultative anaerobic conditions [17]. $B$. licheniformis is one of the bacteria found in the commercial seed in the process of biodegradation of paint wastewater treatment [23].

Bacterial species found in the root tissue of maize plants have similarities with bacterial species in biofertilizers with different strains such as $P$. aeruginosa strain WCHPA075019 on biofertilizer and $P$. aeruginosa strain ATCC 10145 on maize endophytes, B. subtilis subsp. subtilis strain 168 on 
biofertilizer and Bacillus subtilis $H R-4$ on maize endophytes. Endophytic colonization refers to the entry, growth, and multiplication of endophytic populations within the host plant [8]. Other bacterial species $B$. paramycoides and $B$. licheniformis are thought to have originated from the rhizosphere around the maize plant. Maize plants will release exudates in the form of organic acids and amino acids, possibly this exudate is a nutrient for bacteria around the rhizosphere so that it can attract bacteria from the rhizosphere to enter the plant endophytes. Genera Bacillus and Pseudomonas are bacteria that are generally found in plant tissue [29].

Some of the characters of plant endophytic bacteria, namely producing growth-promoting hormones [30] which are often called Plant Growth Bacteria (PGB) with direct or indirect effect mechanisms. IAA is a phytohormone with auxin activity that regulates the development process of plant cells [29, 31]. The results of the research by [13] that the use of $P$. aeruginosa in jatropha plants can act as a biocontrol agent and synthesis of PGP compounds such as IAA, GA3, ACC deaminase, siderophore, and polar substance. According to [14] research inoculation of B. subtilis on wheat, faba, and helba plants in saline conditions can produce the best IAA and $\mathrm{P}$ solvents at $\mathrm{pH}$. IAA produced by bacteria around the roots will enter the plant and stimulate root hair growth and increase nutrient uptake. Biofertilizer sprayed on the leaves will help bind free $\mathrm{N}$ from the air and enter the corn leaf tissue. Biofertilizers containing B. subtilis bacteria can bind $\mathrm{N}$, this can be seen from the relatively high $\mathrm{N}$ nutrient content of maize plants $(3,004-3,027 \%)$ [32].

Endophytic bacteria produce amylase, protease [20], cellulose enzymes [33], produce special metabolites or bioactive compounds biologically [34], phosphate solvent production, N2 fixation [30], anti-bacterial and anti-fungal activity [33]. Plant Growth Bacteria can support plant health by increasing soil fertility, nutrient availability, and absorption by plants [35]. Ref. [6] added that bacterial endosymbionts regulate plant needs for nitrogen as an important macronutrient, so that plant growth increases. The presence of endophytic bacteria in plant tissue can produce phytohormones to stimulate growth and increase plant resistance to disease

Bacteria from the genera Bacillus spp. and Pseudomonas sp. has the potential to bind $\mathrm{N}$ nutrients, increase the solubility of $\mathrm{P}$ and $\mathrm{K}$ (biofertilizer), produce IAA compounds as a growth stimulant (biostimulant), and suppress pathogenic growth (biocontrol). Bacillus spp. and Pseudomonas sp. live in synergy and interact with other microorganisms. [29] emphasized that plant growth-promoting bacteria are bacteria that can increase plant growth and protect plants from disease through various mechanisms. Both genera Bacillus spp. and Pseudomonas sp. who are members of a consortium can produce IAA which increases the growth and production of maize plants [36].

\section{CONCLUSION}

Endophytic bacteria in the roots of maize plants treated with water hyacinth biofertilizer were dominated by four dominant bacterial species, namely $B$. paramycoides $12.1 \times 10^{7} \mathrm{CFU} / \mathrm{ml}, P$. aeruginosa $4.3 \times$ $10^{7} \mathrm{CFU} / \mathrm{ml}$, B. subtilis $9.4 \times 10^{7} \mathrm{CFU} / \mathrm{ml}$, and $B$. licheniformis $5.95 \times 10^{6} \mathrm{CFU} / \mathrm{ml}$. The presence of these endophytic bacteria can stimulate plant growth and increase resistance to diseases.

\section{ACKNOWLEDGMENTS}

The author is grateful to DRPM Kemenristek Dikti for the supported for the grant of Penelitian Dasar Unggulan Perguruan Tinggi (PDUPT).

\section{REFERENCES}

[1] I. Miliute, O. Buzaite, D. Baniulis, V. Stanys, Bacterial Endophytes in Agricultural Crops and Their Role in Stress Tolerance: A review, J. Zemdirbyste Agriculture 102(4) (2015) 465-478. DOI 10.13080/Z-A.2015.102.060.

[2] S. Compant, B. Mitter, J.G. Colli-Mull, H. Gangl, Sessitsch A. Endophytes of Grapevine Flowers, Berries, and Seeds: Identification of Cultivable Bacteria, Comparison with Other Plant Parts, and visualization of Niches of Colonization, J Microbial Ecology 62 (2011) 188-197. DOI 10.1007/s00248-011-9883-y

[3] A.E. Fadiji, O.O. Babalola, Elucidating Mechanisms of Endophytes Used in Plant Protection and Other Bioactivities with Multifunctional Prospects, J. Frontiers in Bioengineering and Biotechnology 8(467) (2020) 1-20. DOI: $10.3389 /$ fbioe. 2020.00467.

[4] E. Khare, J. Mishra, N.K. Arora, Multifaceted Interactions Between Endophytes and Plant: Developments and Prospects, Frontiers Microbiology 9(2732) (2018) 1-12. DOI: 10.3389/fmicb. 2018.02732

[5] I. Tamosiune, D. Baniulis, V. Stanys, Role of endophytic bacteria in stress tolerance of agricultural plants: diversity of microorganisms and molecular mechanisms, in V. Kumar (Eds) Workshop Probiotics in Agroecosystem, vol. 1, Springer Nature Singapore Pte Ltd, 2017, pp. 1-29. DOI: 10.1007/978-981-10-4059-7_1

[6] G. Santoyo, G. Moreno-Hagelsieb, M.D.C. Orozco-Mosqueda, B.R. Glick, Plant GrowthPromoting Bacterial Endophytes, J. 
Microbiological Research 183 (2016) 92-99. http://dx.doi.org/10.1016/i.micres. 2015.11.008

[7] W. Zhong, T. Gu, W. Wang, B. Zhang, X. Lin, Q. Huang, W. Shen, The effects of Mineral Fertilizer and Organic Manure on Soil Microbial Community and Diversity, J. Plant and Soil 326 (2010) 511522.

https://link.springer.com/article/10.1007/s11104009- 9988-y

[8] S.L. Kandel, P.M. Joubert, S.L. Doty, Bacterial Endophyte Colonization and Distribution within Plants. Journal Microorganisms 5(77) (2017) 1-26. DOI 10.3390/microorganisms5040077

[9] S.H. Yoon, S.M. Ha, S. Kwon, J. Lim, Y. Kim, H. Seo, J. Chun, Introducing EzBio Cloud. A Taxonomically United Database of 16S rRNA Gene Sequences and Whole Genome Assemblies. International J. Systematic and Evolutionary Microbiology 67 (2017) 1613-1617.

[10] F. Chi, S.H. Shen, H.P. Cheng, Y.X. Jing, Y.G. Yanni, F.B. Dazzo, Ascending Migration of Endophytic Rhizobia, from Roots to Leaves, Inside Rice Plants and Assessment of Benefits to Rice Growth Physiology. Applied and Environmental $\begin{array}{llll}\text { Microbiology } & 71 & \text { (2005) 7271-7278. }\end{array}$ doi:10.1128/AEM.71.11.7271-7278.2005

[11] W.F.E. Hansen, U.S. Hastuti, S.P. Makkadafi, P.M.A. Asna, S.F.A. Nugraheni, Isolasi dan identifikasi bakteri amilolitik dari tanah yang tercampur limbah kulit ubi kayu di Bondowoso, Jawa Timur, in: Prosiding Seminar Nasional III Tahun 2017 "Biologi, Pembelajaran, dan Lingkungan Hidup Perspektif Interdisipliner", Prodi Pendidikan Biologi-FKIP bekerjasama dengan Pusat Studi Lingkungan dan Kependudukan, Universitas Muhammadiyah Malang, 29 April 2017, pp. 259-262. [In Bahasa Indonesia]

[12] L.R. Silitonga, Nursyirwani, I. Effendi, Isolation, Identification, and Sensitivity of Amilolitic Bacteria from Mangrove Ecosystem Sediment in Purnama Marine Station Dumai on the Pathogenic Bacteria. Asian Journal of Aquatic Sciences 2(3) (2019) 257-266.

[13] R. Kumar, S.K. Soam, Brajendra, Plant Growth Promoting Rhizobacteria (PGPR) in Management of Plant Diseases. Eco-friendly Innovative Approaches in Plant Disease Management, Chapter 13 (2015), pp. $207-240$.

[14] N.M.H. Yousef. Capability of Plant GrowthPromoting Rhizobacteria (PGPR) for Producing Indole Acetic Acid (IAA) Under Extreme Conditions, European Journal of Biological Research. 8(4) (2018) 174-82.

[15] Suryani, A. Muis, Prospek Bacillus subtilis sebagai Agen Pengendali Hayati Patogen Tular Tanah pada Tanaman Jagung. J. Litbang Pertanian 35(1) (2016) 37-45. [In Bahasa Indonesia]

[16] F. Liu, S. Xing, H. Ma, Z. Du, B. Ma, CytokininProducing, Plant Growth-Promoting Rhizobacteria That Confer Resistance to Drought Stress in
Platycladus Orientalis Container Seedlings. J. Applied Microbiology and Biotechnology 97 (2013) 9155-9164.

[17] M.W. Rey, P. Ramaiya, B.A. Nelson, S.D. BrodyKarpin, E.J. Zaretsky et al, Complete Genome Sequence of The Industrial Bacterium Bacillus licheniformis and Comparisons with Closely Related Bacillus Species. J. Genome Biology 5(10) (2004) http://genomebiology.com/2004/5/10/R77

[18] N. Rahmawati, R.S. Budiarti, Harlis. Kajian pembuatan gula cair berbahan dasar kulit singkong (Manihot utilissima Pohl.) dengan pemanfaatan bakteri Bacillus licheniformis. Pendidikan Biologi Jurusan PMIPA FKIP Universitas Jambi. Repository Universitas Jambi. 2017. [In Bahasa Indonesia]

[19] D. Divakaran, A. Chandran, R.P. Chandran, Comparative Study on the Production of a-Amylase from Bacillus licheniformis strains, Brazilian Journal of Microbiology 42 (2011) 1397-1404. DOI: 10.1590/S1517-838220110004000022

[20] M.P.C. Silvestre, H.A. Morais, V.D.M. Silva, M.R. Silva, Monteiro, L.L. Cruz, Hydrolysis of Whey Proteins by a Bacillus licheniformis Protease, Publ. UEPG Ci. Exatas Terra, Ci. Agr. Eng. Porta Grossa 18(2) (2012) 85-94. DOI: 10.5212/Publ.Exatas.v. $18 \mathrm{i} 2.0004$

[21] J.S. Singh, V.C. Pandey, D.P. Singh, Efficient Soil Microorganisms: A New Dimension for Sustainable Agriculture and Environmental Development, Agriculture, Ecosystems \& Environment 140 (2011) 339-353.

[22] D.K. Choudhary, B.N. Johri, Interactions of Bacillus spp. and plant with special reference to induced systemic resistance (ISR), J. Microbiological Research. 164 (2009) 493-513.

[23] Y. Liu, J. Du, Q. Lai, R. Zeng, D. Ye, J. Xu, Z. Shao, Proposal of nine novel species of the Bacillus cereus Group, vol. 67, Interational Journal of Systematic and Evolutionary Microbiology 67 (2017) 2499-2508. DOI 10.1099/ijsem.0.001821.

[24] Y. Sondang, K. Anty, R. Siregar, Identification of endophytic and rhizosphere bacteria in maize (Zea mays L.) in Limapuluh Kota Region, West Sumatra, Indonesia, in: Novizar (Eds) vol. 347, IOP Conference Series: Earth and Environmental Science. (2019) 1-8. DOI: 10.1088/17551315/347/1/012002.

[25] M.K. Cowan, K.P. Talaro, Microbiology a system approach. Mc. Grow-Hill Companies, New York. 2006.

[26] K. Parani, B.K. Saha, Prospects of Using Phosphate Solubilizing of Pseudomonas as Bio Fertilizer, European Journal of Biological Sciences 4 2012) 40-44. DOI:10.5829/idosi.ejbs.2012.4.2.63117

[27] P.K. Pandey, S. Singh, A.K. Singh, R. Samanta, R.N.S. Yadav, M.C. Singh, Inside the Plant: Bacterial Endophytes and Abiotic Stress Alleviation, vol. 8, Journal of Applied and Natural 
Science 8(4) (2016) 1899-1904.

[28] B. Mayanti, H. Ariesyady, Identifikasi Keberagaman Bakteri pada Commercial-Seed Pengolah Limbah Cair Cat, vol. 16, Jurnal Teknik Lingkungan ITB 16(1) (2010) 52-61. [In Bahasa Indonesia]

[29] R.A. Souza, L.M.P. Ambrosini, Passaqlia, Plant growth-Promoting Bacteria as Inoculants In Agricultural Soils, Journal of Genetics and Molecular Biology 38 (4) (2015) 401-419.

[30] B.R. Glick, Plant Growth-Promoting Bacteria: Mechanisms and Applications, Hindawi Publishing Corporation Scientifica. 2012, 15 p. doi: 10.6064/2012/963401.

[31] D. Bhardwaj, M.W. Ansari, R.K. Sahoo, N. Tuteja, Biofertilizers function as Key Players in Sustainable Agriculture by Improving Soil Fertility, Plant Tolerance, and Crop Productivity, Microbial Cell Factories 13(66) (2014) 1-10.

[32] Y. Sondang, K. Anty, R. Siregar, Aplikasi pupuk organik hayati eceng gondok pada budidaya jagung (Zea mays L.) sistem legowo-2, in Proseding Seminar Nasional Terapan Riset Inovatif (SENTRINOV) Ke-6. Series: Engineering and Science 6 2010, pp. 1224-1232. [In Bahasa Indonesia]

[33] R. Vijayalakshmi, K. Kairunnisa, S.N. Sivvaswamy, S.S. Dharan, S. Natarajan, Enzyme Production and Antimicrobial Activity of Endophytic bacteria isolated from medicinal plants, Indian Journal of Science and Technology 9 (2016) pp. 1-8. DOI: 10.17485/ijst/2016/v9i14/83143.

[34] O. Liarzi, P. Bucki, M. Braun, D. Ezra, Bioactive volatiles from an endophytic Daldinia cf. concentric isolate affect the viability of the plantparasitic nematode Meloidogyne javatica, J. PloS One 11 (2016). https://doi:10.1371/journal.pone.0168437.

[35] V. Nehra, B.S. Sahara, M. Choudhary, Evaluation of Brevibacillus brevis as a Potential Plant Growth Promoting Rhizobacteria for Cotton (Gossypium hirsutum) Crop, SpringerPlus 5(948) (2016) DOI: 10.1186/s40064-016-2584-8.

[36] Y. Sondang, R. Siregar, K. Anty, Penerapan pupuk hayati dalam meningkatkan produksi jagung (Zea mays L.) di Kabupaten Limapuluh Kota, in: Proseding Seminar Nasional Pemberdayaan Masyarakat, Pekanbaru vol. 1, Unri Conference Series: Community Engagement. 2019, pp. 202209. DOI:https://doi. org/10.31258/unricsce. 1.202209. [In Bahasa Indonesia] 